\title{
DESAIN FREEBOARD MINIMUM TERHADAP KESELAMATAN DAN PENGURANGAN BIAYA OPERASIONAL KAPAL PERIKANAN 30 GT DI PERAIRAN SULAWESI (STUDI KASUS KM INKA MINA 759)
}

\author{
MINIMUM FREEBOARD DESIGN ON SAFETY AND OPERATIONAL COST \\ REDUCING OF A 30 GT FISHING VESSEL IN SULAWESI WATERS \\ (CASE STUDY OF KM INKA MINA 759)
}

\author{
Andi Haris Muhammad*, Baharuddin, dan Hasnawiya Hasan \\ Departemen Teknik Sistem Perkapalan, FTUH, Makassar \\ *E-mail: andi_haris@ft.unhas.ac.id
}

\begin{abstract}
Fishing vessels are generally designed with special missions to locate, capture, and preserve fish, while the vessel must have a good level of safety, low operation costs and environmentally friendly. This study aims to improve the safety level and reduce operational cost of 30 GT fishing vessel through minimum freeboard design. Maxsurf program package has been used in dimension modeling, hull form design, stability and resistance prediction on 4 (four) hull form models analyzed $\left(K_{1}, K_{2}, K_{3}\right.$ and $\left.K_{4}\right)$. The results show that the hull form of $K_{2}$ with the wider dimension ratio $(L / B=4.98, B / D=$ 3.26, $B / T=4.80, D / T=1.47)$ has a level of stability better than 3 (three) other hull form models $\left(K_{1}, K_{3}\right.$ and $K_{4}$ ), while the highest reduction of resistance value is shown by hull form model of $K_{3}$ with a slimmer main dimension ratio $(L / B=6.43, B / D=2.78 ; B / T=4.09 ; D / T=1.47)$. In general, the four models of hull forms analyzed deserve to be operated in accordance with the IMO criteria.
\end{abstract}

Keywords: fishing vessel, minimum freeboard, safety and economical

\begin{abstract}
ABSTRAK
Kapal perikanan umumnya dirancang dengan misi khusus untuk menemukan, menangkap, dan mengawetkan ikan, sementara itu kapal harus memiliki tingkat keselamatan yang baik, biaya operasional yang rendah serta ramah lingkungan. Penelitian ini bertujuan untuk meningkatkan tingkat keselamatan dan pengurangan biaya operasional kapal perikanan 30 GT melalui desain freeboard minimum. Paket program Maxsurf telah digunakan dalam pemodelan dimensi, desain bentuk kasko, prediksi stabilitas dan resistensi pada 4 (empat) model kasko yang dianalisis $\left(K_{1}, K_{2}, K_{3}\right.$ dan $\left.K_{4}\right)$. Hasil penelitian menunjukkan bahwa bentuk kasko $K_{2}$ dengan rasio dimensi utama lebih lebar $(L / B=4,98$; $B / D=3,26 ; B / T=4,80 ; D / T=1,47)$ memiliki tingkat stabilitas yang lebih baik dibandingkan 3 (tiga) model kasko lainnya $\left(K_{l}, K_{3}\right.$ dan $\left.K_{4}\right)$, sementara pengurangan nilai resistensi tertinggi ditunjukkan oleh model bentuk kasko $K_{3}$ dengan rasio dimensi utama lebih ramping $(L / B=6,43 ; B / D=2,78 ; B / T=4,09$; $D / T=1,47)$. Secara umum, keempat model bentuk kasko yang dianalisis layak dioperasikan sesuai dengan kriteria $I M O$.
\end{abstract}

Kata kunci: kapal perikanan, freeboard minimum, stabil dan ekonomis

\section{PENDAHULUAN}

Sejumlah teknologi penghematan energi pada kapal telah diterapkan untuk mengurangi konsumsi bahan bakar dan emisi gas buang ke atmosfer, hal ini terkait dengan peningkatan harga produk minyak yang digunakan pada kapal (biaya bahan bakar, minyak dan pelumas adalah $50-80 \%$ dari biaya operasi kapal) dan sesuai dengan persyaratan IMO (International Maritime Organisation) terkait dengan perlindungan lingkungan. Behrendt (2014) menjelaskan teknologi hemat energi yang pernah diterapkan pada sejumlah kapal perikanan, pengurangan terbesar bahan bakar kapal yaitu berkisar $8-10 \%$ melalui pengoptimuman bentuk kasko. 
Pengoptimuman bentuk kasko kapal dapat menyebabkan pengurangan konsumsi bahan bakar minyak melalui pengurangan total resistensi kapal $\left(R_{T}\right)$. Pengoptimuman ini signifikan dipengaruhi oleh rasio panjang terhadap lebar kapal $(L / B)$ dan rasio lebar terhadap sarat kapal $(B / T)$ serta koefisien balok kapal $(C b)$. Karakteristik sejumlah kapal perikanan dengan alat tangkap purse seine yang beroperasi di perairan Sulawesi umumnya memiliki bentuk kasko yang ramping dengan stabilitas yang baik (Nurdin et al., 2013, Muhammad et al., 2015 dan Azis et al., 2017). Fenomena yang berkembang saat ini, kapal perikanan selain di desain berdasarkan rasio $L / B, B / T$ dan rasio tinggi terhadap sarat kapal $(D / T)$ yang sesuai dengan pemenuhan kecepatan serta kriteria keselamatan kapal. Hendaknya pula kapal perikanan didesain untuk mampu menahan beban samping ketika kapal menarik peralatan tangkap (purse seiner), kapal memiliki geladak kerja yang luas dan mudah menaikan hasil tangkapan ke geladak melalui rancangan kapal dengan rasio $D / T$ yang relatif rendah atau freeboard minimum.

Freeboard atau lambung timbul adalah jarak vertikal antara garis geladak lambung timbul ke arah bawah hingga sisi atas garis muat yang diukur pada tengah kapal. Kuroda et al. (2003) dalam penelitiannya menyampaikan bahwa kapal dengan $D / T$ yang relatif rendah atau freeboard minimum umumnya rawan terhadap risiko terbalik (capsizing) dibanding dengan kapal yang memiliki freeboard yang lebih tinggi. Saat kapal dioperasikan dengan kondisi laut bergelombang yang dipengaruhi oleh panjang dan tinggi gelombang serta kecepatan operasi kapal. Kapal dengan freeboard minimum sangat rentan terhadap bahaya kehilangan stabilitas (pure loss stability) (Chorab, 2014). Namun kondisi tersebut diatas membaik melalui penambahan lebar kapal $(B)$ dan pengaturan titik $G M$ (Paroka dan Umeda, 2007). Penelitian ini bertujuan untuk meningkatkan tingkat keselamatan dan pengurangan biaya operasional kapal perikanan 30 GT melalui pemodelan desain freeboard minimum.

\section{METODE PENELITIAN}

\subsection{Waktu dan Tempat Penelitian}

Penelitian dilaksanakan selama 8

Bulan (April - November 2017) yang berpusat di Laboratorium Riset Propulsi Kapal, Departemen Teknik Sistem Perkapalan, Fakultas Teknik Universitas Hasanuddin.

\subsection{Bahan dan Data}

Kapal perikanan sebagai sampel dalam penelitian ini adalah KM INKA MINA 759 yang beroperasi di perairan Sulawesi. Kapal berkapasitas 30 GT dengan alat tangkap tipe purse-seiner, daya motor propulsi $\left(P_{B}=170 \mathrm{hp}\right)$ dan dioperasikan pada kecepatan jelajah $\left(V_{S}=11\right.$ knot). KM INKA MINA 759 merupakan kapal yang memiliki rasio dimensi utama masuk dalam rentang ukuran kasko kapal pada umumnya di Indonesia, khususnya kelompok encircling gear (Iskandar dan Pujiati, 1995) dan kapal tersebut memiliki karakteristik performa yang baik (Muhammad et al., 2015 dan 2017). Kapal dioperasikan dengan dua (2) kondisi pemuatan yaitu; i) Kondisi pemuatan penuh; kapal beroperasi dan meninggalkan lokasi penangkapan (fishing ground) dengan pemuatan penuh ( $\Delta_{P}=65,71$ ton); ii) Kondisi pemuatan kosong; kapal meninggalkan pelabuhan dan beroperasi di lokasi penangkapan dengan pemuatan kosong ( $\Delta_{K}=46,67$ ton). Bentuk model kasko dan data dimensi utama kapal sampel sebagaimana Gambar 1 dan Tabel 1.

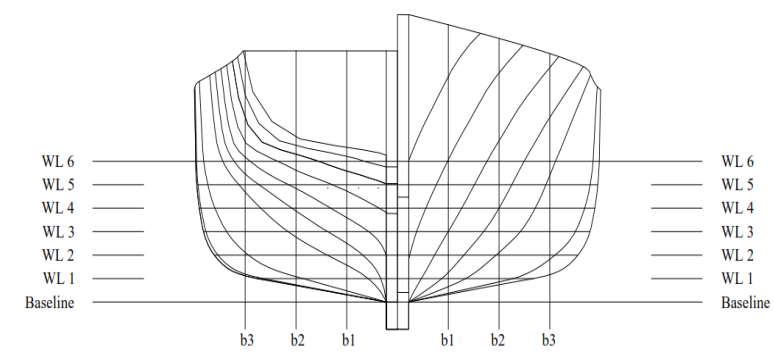

Gambar 1. Bentuk model kasko kapal sampel $\left(K_{1}\right)$. 
Tabel 1. Dimensi utama kapal sampel $\left(K_{l}\right)$.

\begin{tabular}{lc}
\hline \multicolumn{1}{c}{ Uraian } & Dimensi \\
\hline Panjang keseluruhan, & 26,30 \\
Loa $(\mathrm{m})$ & 4,50 \\
Lebar, $B(\mathrm{~m})$ & 1,80 \\
Tinggi, $D(\mathrm{~m})$ & 1,20 \\
Sarat, $T(\mathrm{~m})$ & 11 \\
Kecepatan jelajah, & \\
$V_{S}($ knot $)$ & 65,71 \\
Displasmen penuh, & 0,618 \\
$\Delta_{P}($ ton $)$ & \\
Koefisien prismatik &
\end{tabular}

\subsection{Metode Analisis}

Pemodelan bentuk kasko merupakan tahap awal dalam desain freeboard minimum $(f=D-T)$, dimana pemodelan ini penting untuk mengetahui bentuk dan karakteristik model kasko yang dihasilkan. Paket Program Maxsurf digunakan dalam pemodelan model kasko sesuai dengan displasmen dan koefisien primastik kapal sampel. Pendekatan penentuan desain freeboard minimum $(f \geq$ $D / 15+0,2)$ dijadikan acuan dalam pemodelan sebagaimana yang disyaratkan pada desain kapal perikanan pemerintah Jepang pada tinggi kasko $(D<6 \mathrm{~m})$ dan panjang $(L<40 \mathrm{~m})$ (Kuroda et al., 2003). Persamaan diatas memiliki korelasi dalam penentuan freeboard minimum kapal yang beroperasi di perairan Pinrang dan Bulukumba Sulawesi Selatan sebagaimana maisnh-masing data kapal dalam penelitian Azis et al. (2017) dan Nurdin et al. (2013).

Terdapat empat (4) bentuk model kasko yang yang akan dianalisis dalam penelitian ini (termasuk kapal sampel): i) Kasko $1\left(K_{l}\right)$ merupakan model kasko kapal sampel; ii) Kasko $2\left(K_{2}\right)$ merupakan model kasko dengan penurunan freeboard $(f)$ melalui penambahan lebar kapal $(B w l)$; iii) Kasko $3 \quad\left(K_{3}\right)$ merupakan model kasko dengan penurunan freeboard $(f)$ melalui penambahan panjang kapal $(L w l)$ selanjutnya; iv) Kasko $4\left(K_{4}\right)$ merupakan model kasko dengan penurunan freeboard $(f)$ melalui kombinasi penambahan lebar $(B \mathrm{wl})$ dan panjang kapal ( $L w l)$. Untuk melihat tingkat keselamatan kapal hasil pemodelan, analisis stabilitas model kasko diperlukan, khususnya pada kondisi: i) kondisi pemuatan penuh; ii) kondisi pemuatan kosong serta; iii) kondisi saat terjadinya perubahan titik berat vertikal $(K G)$. Analisis stabilitas (intact stability) dalam menentukan tingkat kestabilan kapal (GZ) pada kondisi laut tidak bergelombang didasarkan pada kriteria IMOA749 (2002). Selanjutnya untuk melihat pengurangan biaya operasional kapal yang bersumber dari jumlah bahan bakar minyak yang digunakan, prediksi resistensi pada kondisi pemuatan penuh dan kosong perlu dianalisis. Prediksi resistensi model kasko menggunakan Metode Holtrop (Holtrop and Mennen, 1982 dan Holtrop, 1984).

\section{HASIL DAN PEMBAHASAN}

Gambar 2 menampilkan 4 (empat) model kasko hasil pemodelan melalui Paket Program Maxsurf pada displasmen penuh $\left(\Delta_{P}=65,71\right.$ Ton) dan koefisien prismatik $\left(C_{P}=0,618\right)$ sebagaimana data kapal sampel pada Tabel 1. Kasko $1\left(K_{l}\right)$ merupakan model kasko kapal sampel sebagaimana dimensi utama pada Tabel 1. Kasko $1\left(K_{l}\right)$ tersebut merupakan kasko standar dalam pemodelan Kasko $K_{2}, K_{3}$ dan $K_{4}$. Kasko hasil pemodelan $\left(K_{2}, K_{3}\right.$ dan $\left.K_{4}\right)$ masing-masing memiliki dimensi tinggi $(D)$ dan sarat $(T)$ yang lebih rendah yaitu sebesar $17 \%$ dan $15 \%$ dibanding Kasko $1\left(K_{1}\right)$, hal ini dikarenakan penurunan freeboard kapal. Namun demikian untuk mempertahankan displasmen dan koefisien prismatik kapal ketiga kasko hasil pemodelan memiliki penambahan lebar sebesar $15 \%$ pada kasko 2 $\left(K_{2}\right)$, penambahan panjang $9,3 \%$ pada kasko $3\left(K_{3}\right)$ dan penambahan lebar dan panjang masing-masing 7,7\% dan 7,9\% pada kasko 4 $\left(K_{4}\right)$. Hasil pemodelan freeboard $(H-T)$ yaitu sebesar $0,48 \mathrm{~m}$, desain freeboard ini lebih besar sebagaimana disyaratkan pada pemerintah Jepang yaitu minimal $0,3 \mathrm{~m}$. 
Dimensi utama model kasko hasil pemodelan ditampilkan sebagaimana pada Tabel 2.

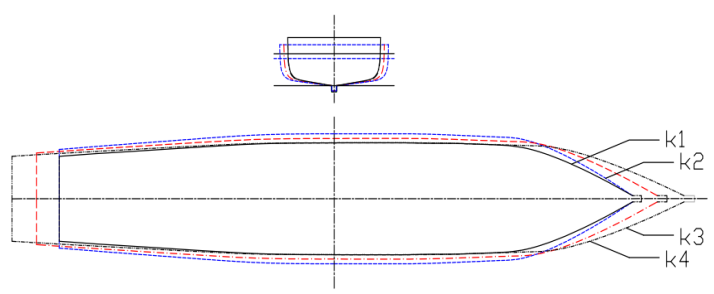

Gambar 2. Bentuk model kasko kapal sampel dan hasil pemodelan.

Tabel 3 menampilkan rasio dimensi kasko kapal hasil pemodelan $\left(K_{2}, K_{3}\right.$, dan $\left.K_{4}\right)$. Rasio dimensi tersebut masuk dalam rentang ukuran kasko kapal pada umumnya di Indonesia untuk kelompok encircling gear (Iskandar dan Pujiati, 1995), kecuali rasio $L / D$ pada Model Kasko $K_{3}$ lebih besar sebagaimana acuan tersebut. Iskandar dan Pujiati (1995) menyebutkan bahwa semakin besar nilai $L / D$ maka akan berdampak pada lemahnya kekuatan memanjang kapal.
Sesuai dengan misi dan operasi kapal perikanan, kapal senantiasa mengalami perubahan pemuatan yang bergantung pada jumlah hasil tangkapan. Perubahan pemuatan ini secara langsung berdampak pada perubahan titik berat baik secara tegak maupun memanjang kapal. Gambar 3a dan $3 \mathrm{~b}$ menunjukan perkiraan batasan titik berat tegak maksimal $(K G)$ dan memanjang ( $L C G)$ yang didasarkan pada displasmen kapal melalui bantuan Paket Program Hidromax. $K G$ atau jarak tegak antara lunas dan titik berat kapal sebagaimana Gambar 3a, model kasko $K_{l}$ diprediksi memiliki $K G$ maksimum tertinggi sesuai ketentuan IMO A (749) 18 yaitu 1,79 m pada muatan penuh $\left(\Delta_{P}=65,71\right.$ ton) dan $1,93 \mathrm{~m}$ pada muatan kosong $\left(\Delta_{K}=\right.$ 46,67 ton), nilai ini lebih tinggi dibanding tiga model kasko lainnya sebagaimana ditampilkan pada Tabel 4. Pergeseran titik $K G$ ini selain dipengaruhi pergeseran displasmen kapal, juga dipengaruhi oleh bentuk kasko kapal atau rasio $B / D$ (Zhao, 1997).

Tabel 2. Dimensi utama model kasko kapal sampel dan hasil pemodelan.

\begin{tabular}{lcccc}
\hline \multirow{2}{*}{ Dimensi } & \multicolumn{4}{c}{ Model kasko } \\
\cline { 2 - 5 } & $K_{1}$ & $K_{2}$ & $K_{3}$ & $K_{4}$ \\
\hline Panjang keseluruhan $($ Loa $), \mathrm{m}$ & 26,30 & 26,25 & 30,74 & 28,42 \\
Panjang $(L w l), \mathrm{m}$ & 24,35 & 24,35 & 26,85 & 26,45 \\
Lebar $(B w l), \mathrm{m}$ & 4,17 & 4,89 & 4,17 & 4,52 \\
Tinggi $(D), \mathrm{m}$ & 1,80 & 1,50 & 1,50 & 1,50 \\
Sarat $(T), \mathrm{m}$ & 1,20 & 1,02 & 1,02 & 1,02 \\
Freeboard $(D-T)$ & 0,60 & 0.48 & 0,48 & 0,48 \\
Freeboard (Pers. 1) & 0,32 & 0,30 & 0,30 & 0,30 \\
Displasmen penuh $\left(\Delta_{P}\right)$, ton & 65,74 & 65,77 & 65,74 & 65,74 \\
Koefisien balok $(C b)$ & 0,45 & 0,45 & 0,45 & 0,45 \\
\hline
\end{tabular}

Tabel 3. Rasio dimensi model kasko kapal sampel dan hasil pemodelan.

\begin{tabular}{cccccc}
\hline \multirow{2}{*}{ Rasio } & Nilai Acuan & \multicolumn{4}{c}{ Model kasko } \\
\cline { 3 - 6 } & (Iskandar dan Pujiati, 1995) & $K_{1}$ & $K_{2}$ & $K_{3}$ & $K_{4}$ \\
\hline$L / B$ & $2,60-9,30$ & 5,84 & 4,98 & 6,43 & 5,85 \\
$L / D$ & $4,55-17,45$ & 13,53 & 16,23 & 17,90 & 17,63 \\
$B / D$ & $0,56-5,00$ & 2,32 & 3,26 & 2,78 & 3,01 \\
$B / T$ & - & 3,48 & 4,80 & 4,09 & 4,43 \\
$D / T$ & - & 1,50 & 1,47 & 1,47 & 1,47 \\
\hline
\end{tabular}




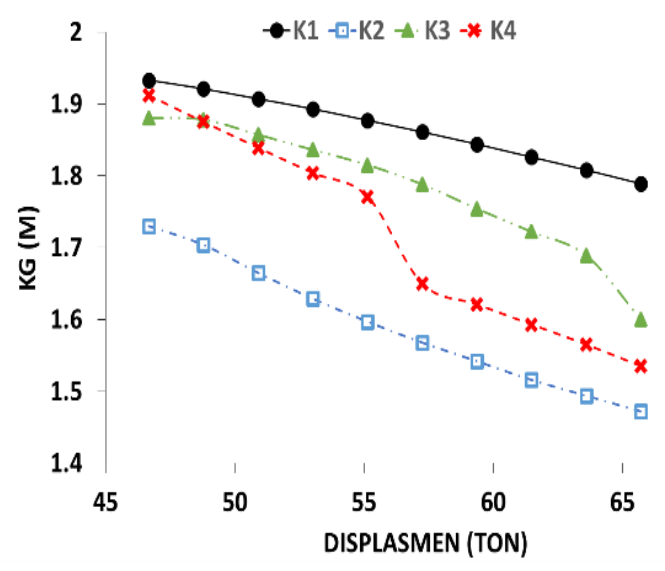

(a)

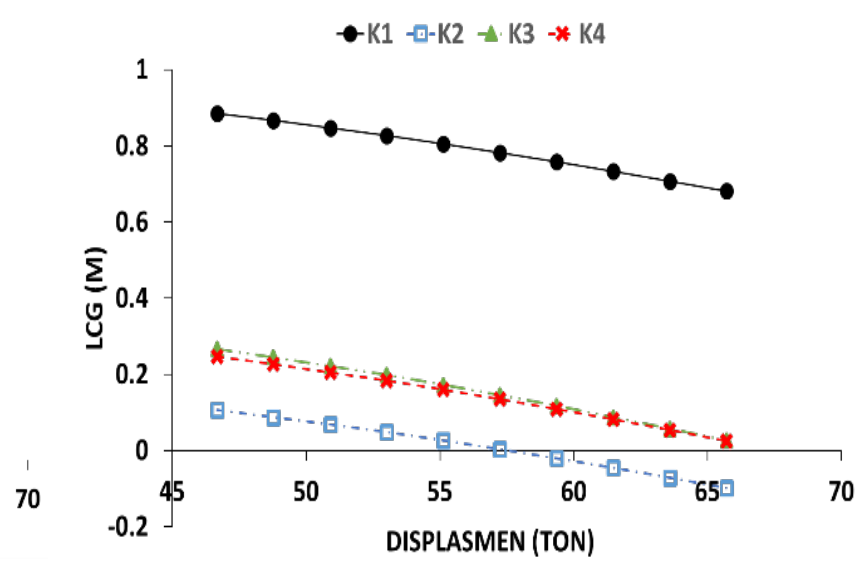

(b)

Gambar 3. Titik berat ( $K G$ dan $L C G$ ) kasko kapal. (a) $K G$ model kasko dan (b) $L C G$ model kasko.

Tabel 4. Displasmen dan titik berat model kasko kapal.

\begin{tabular}{lcccccccc}
\hline & \multicolumn{3}{c}{ Pemuatan penuh $\left(\Delta_{P}\right)$} & \multicolumn{4}{c}{ Pemuatan kosong $\left(\Delta_{K}\right)$} \\
\cline { 2 - 8 } Kondisi kapal & \multicolumn{3}{c}{ Model kasko } & \multicolumn{4}{c}{ Model kasko } \\
\cline { 2 - 8 } & $K_{1}$ & $K_{2}$ & $K_{3}$ & $K_{4}$ & $K_{1}$ & $K_{2}$ & $K_{3}$ & $K_{4}$ \\
\hline Displasmen, ton & 65,71 & 65,71 & 65,71 & 65,71 & 46,67 & 46,67 & 46,67 & 46,67 \\
$K G, \mathrm{~m}$ & 1,789 & 1,472 & 1,6 & 1,535 & 1,933 & 1,73 & 1,88 & 1,912 \\
$L C G, \mathrm{~m}$ & 0,681 & $-0,099$ & 0,026 & 0,024 & 0,885 & 0,227 & 0,266 & 0,246 \\
\hline
\end{tabular}

Gambar 4 menampilkan kurva stabilitas statis 4 (empat) model kasko $\left(K_{l}\right.$, $K_{2}, K_{3}$ dan $K_{4}$ ), sesuai kriteria $I M O$ ke empat model kasko yang di analis aman dioperasikan. Model kasko $K_{l}(B / D=2,32)$ dengan displasmen pemuatan penuh $\left(\Delta_{P}=\right.$ 65,71 ton), diasumsikan saat kapal beroperasi meninggalkan lokasi penangkapan (fishing ground). Hasil analisis menunjukkan bahwa model kasko $K_{l}$ dengan nilai $G Z$ maksimum sebesar $0,215 \mathrm{~m}$.rad pada sudut $28^{\circ}$, nilai $G Z$ maksimum yang dibentuk ini lebih besar 0,015 sebagaimana yang disyaratkan IMO yaitu $0,200 \mathrm{~m} . \mathrm{rad}$. Selanjutnya berturut-turut hasil analisis stabilitas model kasko $K_{3}$ $(B / D=2,78)$ memiliki nilai $G Z$ maksimum sebesar $0,241 \mathrm{~m}$. rad pada sudut $25^{\circ}$; model kasko $K_{4}(B / D=3,01)$ memiliki nilai $G Z$ maksimum sebesar 0,375 m.rad pada sudut $25^{\circ}$; model kasko $K_{2}(B / D=3,26)$ memiliki nilai $G Z$ maksimum sebesar $0,473 \mathrm{~m} . \mathrm{rad}$ pada sudut $26^{\circ}$. Nilai $G Z$ model kasko $K_{2}$ ini lebih tinggi masing-masing 55\%, $49 \%$ dan $21 \%$ dibanding dengan desain model kasko $K_{1,} K_{3}$ dan $K_{4}$.

Selanjutnya analisis stabilitas statis masing-masing model kasko pada muatan kosong ( $\Delta_{P}=46,67$ ton), diasumsikan saat kapal meninggalkan pelabuhan atau beroperasi di lokasi penangkapan. Hasil simulasi menunjukkan sebagaimana pada muatan penuh, model kasko $K_{2}$ memiliki nilai $G Z$ maksimum sebesar $0,492 \mathrm{~m}$.rad pada sudut $26^{\circ}$. Nilai $G Z$ model kasko $K_{2}$ ini lebih tinggi masing-masing $55 \%, \quad 49 \%$ dan $36 \%$ dibanding dengan desain model kasko $K_{1}, K_{3}$ dan $K_{4}$ dengan nilai $G Z$ maksimum masingmasing sebesar 0,217, 0,247 m.rad dan 0,312 m.rad pada sudut $29^{\circ}, 26^{\circ}$ dan $25^{\circ}$. Sesuai nilai $G Z$ maksimum dari masing-masing model kasko yang di analis menunjukkan bahwa model kasko $K_{2}$ memiliki stabilitas yang baik. Meningkatnya tingkat stabilitas kapal secara langsung meningkatkan 
keselamatan kapal saat dioperasikan. Hasil lengkap simulasi pengujian stabilitas awal berdasarkan titik $K G$ maksimum ditampilkan sebagaimana pada Tabel 5.

Tingginya nilai $G Z$ pada model kasko $K_{2}, K_{3}$ dan $K_{4}$ dibanding kapal sampel $\left(K_{l}\right)$ pada 2 (dua) kondisi pengujian (muatan penuh dan kosong) sangat signifikan dipengaruhi oleh meningkatnya rasio $B / D$, namun sebaliknya model kasko $K_{l}$ memiliki sudut $G Z$ maksimum terbesar dibanding model kasko $K_{2}, K_{3}$ dan $K_{4}$, besarnya sudut

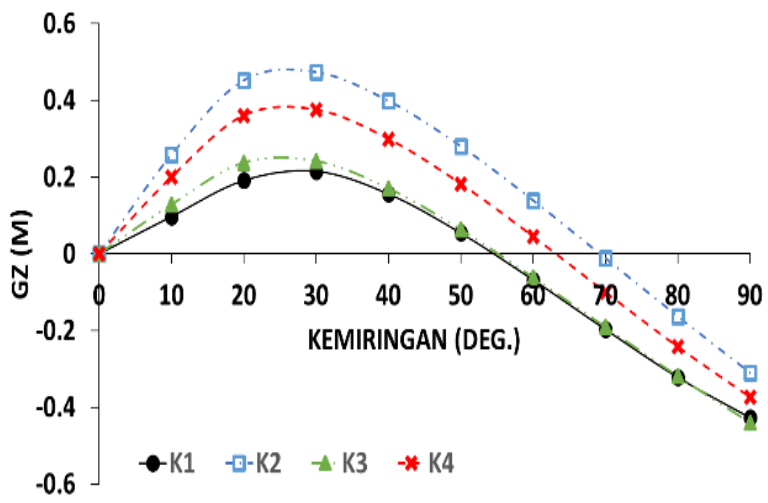

(a)
$G Z$ maksimum ini dipengaruhi rasio $D / T$ atau kapal memiliki freeboard yang lebih besar. Hasil serupa seiring dengan meningkatnya rasio $B / D$ dapat meningkatkan nilai $G Z$ ditunjukkan pula dalam penelitian Nurdin et al. (2014) dan Azis et al. (2017) pada masing-masing sampel kapal perikanan yang beroperasi di perairan Pinrang dan Bulukumba Sulawesi Selatan serta penelitian Susanto et al. (2011) pada kapal sampel di Palabuhanratu Jawa Barat.

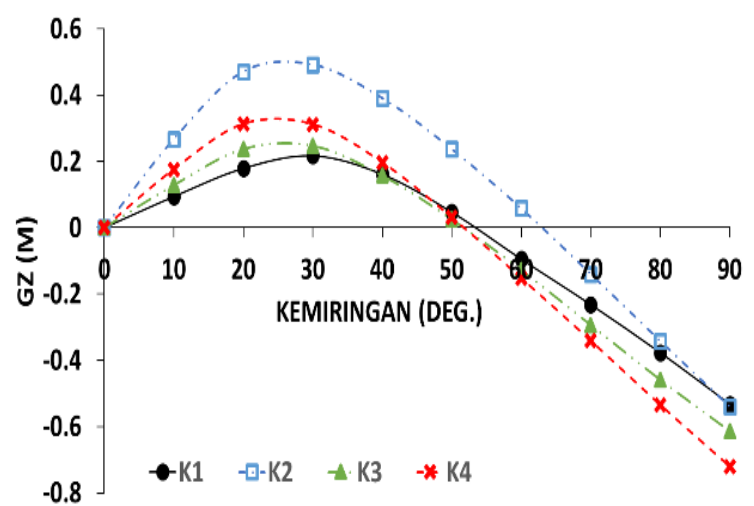

(b)

Gambar 4. Kurva stabilitas statis model kasko kapal dengan $K G$ Maksimum. (a) Pemuatan penuh dan (b) Pemuatan kosong.

Tabel 5. Nilai stabilitas statis model kasko kapal dan nilai rekomendasi IMO.

\begin{tabular}{|c|c|c|c|c|c|c|c|c|}
\hline \multirow{3}{*}{$\begin{array}{c}\text { Kriteria IMO } \\
\text { A.749(18) }\end{array}$} & \multicolumn{4}{|c|}{$\begin{array}{l}\text { Pemuatan Penuh } \\
\qquad\left(\Delta_{P}\right)\end{array}$} & \multicolumn{4}{|c|}{$\begin{array}{l}\text { Pemuatan Kosong } \\
\qquad\left(\Delta_{K}\right)\end{array}$} \\
\hline & \multicolumn{4}{|c|}{ Model Kasko } & \multicolumn{4}{|c|}{ Model Kasko } \\
\hline & $K_{1}$ & $K_{2}$ & $K_{3}$ & $K_{4}$ & $K_{1}$ & $K_{2}$ & $K_{3}$ & $K_{4}$ \\
\hline $\begin{array}{l}\text { Luas 0-30 } \geq 3,151 \\
\text { (m.deg) }\end{array}$ & 4,055 & 9,730 & 4,992 & 7,678 & 3,898 & 10,120 & 5,030 & 6,658 \\
\hline $\begin{array}{l}\text { Luas } 0-40 \geq 5,157 \\
\text { (m.deg) }\end{array}$ & 5,968 & 14,135 & 7,092 & 11,103 & 5,858 & 14,604 & 7,110 & 9,273 \\
\hline $\begin{array}{l}\text { Luas } 30-40 \geq 1,719 \\
\text { (m.deg) }\end{array}$ & 1,914 & 4,405 & 2,100 & 3,426 & 1,961 & 4,483 & 2,080 & 2,615 \\
\hline $\begin{array}{l}\text { Maks GZ pada } 30 \\
\geq 0,2(\mathrm{~m})\end{array}$ & 0,215 & 0,473 & 0,241 & 0,375 & 0,217 & 0,492 & 0,247 & 0,312 \\
\hline $\begin{array}{l}\text { Sudut maks, GZ } \geq \\
25 \text { (deg) }\end{array}$ & 28 & 26 & 25 & 26 & 29 & 26 & 26 & 25 \\
\hline $\begin{array}{l}\text { GMt awal } \geq 0,150 \\
\text { (m) }\end{array}$ & 0,576 & 1,490 & 0,726 & 1,158 & 0,536 & 1,552 & 0,736 & 1,023 \\
\hline
\end{tabular}


Selain dipengaruhi rasio $B / D$, nilai $G Z$ pula sangat dipengaruhi tinggi titik berat $(K G)$ sesuai pengaturan muatan (Marjoni et al., 2010 dan Novita et al., 2014). Gambar 5 menampilkan kurva hasil simulasi stabilitas statis terhadap penurunan titik berat kapal pada masing-masing model kasko $\left(K_{1}, K_{2}, K_{3}\right.$ dan $\left.K_{4}\right)$. Penurunan nilai $K G$ melalui pengaturan letak palka ikan, pemilihan dan penempatan jenis material kasko dan bangunan atas serta peletakan permesinan dan perlengkapan kapal. Selanjutnya dengan meningkatnya nilai $G Z$ secara langsung dapat meningkatkan rentang stabilitas kapal.

Gambar 6 menunjukkan hasil prediksi resistensi model kasko antara kecepatan 9 14 knot. Pada kecepatan jelajah $\left(V_{S}=11\right.$ knot $)$ terdapat pengurangan resistensi sebesar

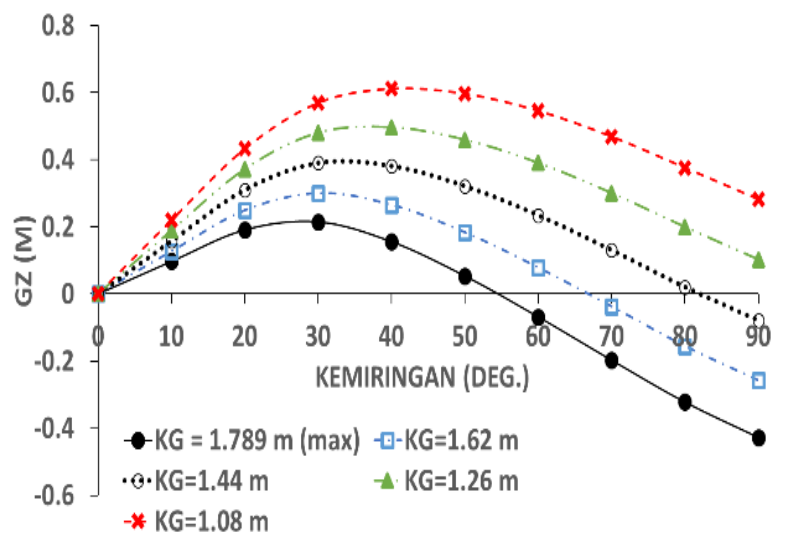

(a)

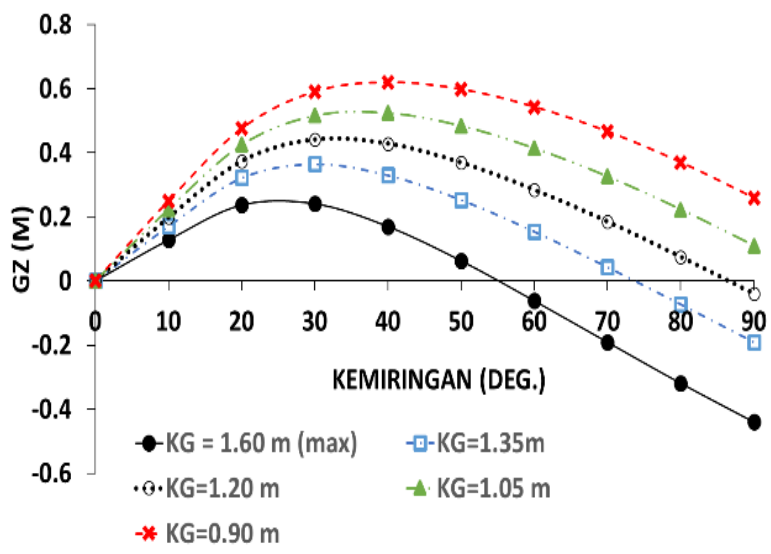

(c)
$19,89 \%$ untuk model kasko $K_{3}(L / B=6,43)$ dan $9,94 \%$ untuk model kasko $K_{4}(L / B=5,85)$ dibanding model kasko $K_{I}$ (kapal sampel) $(L / B=5,84)$, sementara untuk model kasko $K_{2}$ $(L / B=4,98)$ terjadi penambahan resistensi sebesar 3,82\%. Lebih lanjut seiring dengan penambahan kecepatan pada model kasko $K_{3}$ terjadi pengurangan resistensi berturut-turut sebesar $29,97 \%$ dan $27,12 \%$ pada kecepatan $V_{S}=12$ knot dan $V_{S}=13$ knot, fenomena penurunan resistensi ini terjadi pula pada model kasko $K_{4}$, namun pada model kasko $K_{2}$ sebaliknya. Pengurangan atau penambahan besaran resistensi ini dipengarui sebagai akibat rasio $L / B$. Rekapitulasi hasil prediksi resistensi model kasko ditampilkan pada Tabel 6.

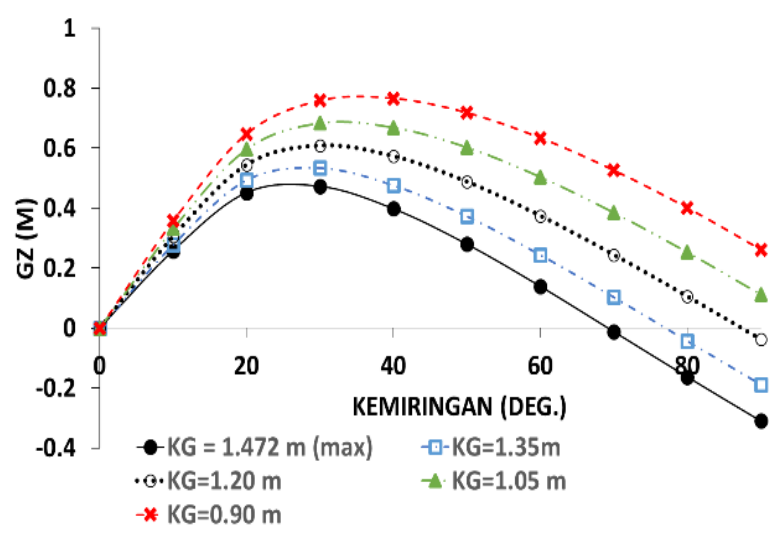

(b)

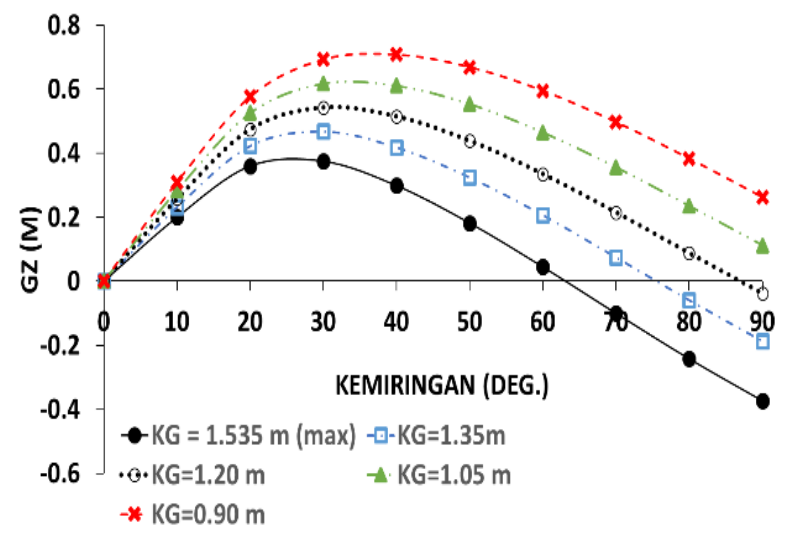

(d)

Gambar 5. Kurva stabilitas statis model kasko dengan variasi $K G$. (a) Model kasko $K_{l}$, (b) Model kasko $K_{2}$, (c) Model kasko $K_{3}$, dan (d) Model kasko $K_{4}$. 


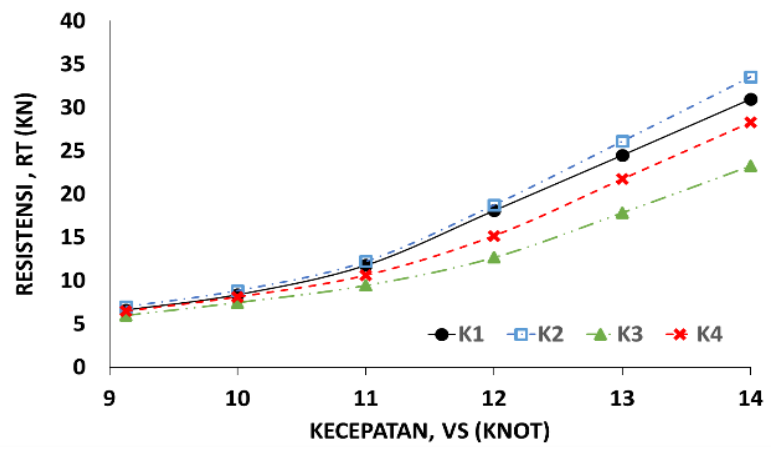

(a)

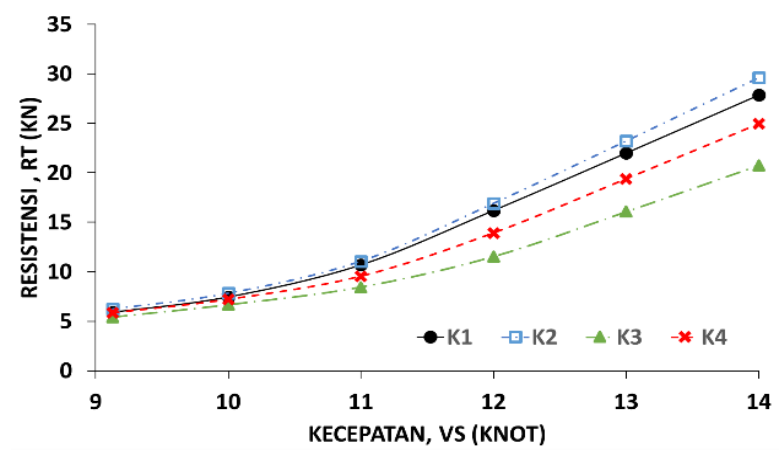

(b)

Gambar 6. Kurva resistensi total model kasko kapal. (a) Pemuatan penuh dan (b) Pemuatan kosong.

Tabel 6. Prediksi resistensi total model kasko kapal.

\begin{tabular}{ccccccccc}
\hline \multirow{2}{*}{$\begin{array}{c}\text { Kecepatan } \\
\text { (knot) }\end{array}$} & \multicolumn{4}{c}{ Pemuatan penuh $\left(\Delta_{P}\right)$} & \multicolumn{4}{c}{ Pemuatan kosong $\left(\Delta_{K}\right)$} \\
\cline { 2 - 9 } & \multicolumn{4}{c}{ Model kasko } & \multicolumn{4}{c}{ Model kasko } \\
\cline { 2 - 9 } & $K_{1}$ & $K_{2}$ & $K_{3}$ & $K_{4}$ & $K_{1}$ & $K_{2}$ & $K_{3}$ & $K_{4}$ \\
\hline 9 & 6,60 & 6,98 & 5,96 & 6,45 & 5,92 & 6,24 & 5,42 & 5,84 \\
10 & 8,37 & 8,84 & 7,45 & 8,09 & 7,46 & 7,83 & 6,67 & 7,21 \\
11 & 11,76 & 12,21 & 9,42 & 10,59 & 10,70 & 11,07 & 8,45 & 9,54 \\
12 & 18,08 & 18,73 & 12,66 & 15,16 & 16,20 & 16,92 & 11,54 & 13,92 \\
13 & 24,48 & 26,09 & 17,84 & 21,72 & 22,00 & 23,23 & 16,07 & 19,39 \\
14 & 30,96 & 33,52 & 23,27 & 28,27 & 27,86 & 29,63 & 20,75 & 24,95 \\
\hline
\end{tabular}

Lebih lanjut penurunan resistensi total kapal yang dikarenakan perubahan rasio dimensi kapal atau rasio dimensi freeboard sangat mempengaruhi besaran koefisien tahanan gesek dan gelombang (sisa). Gambar $7 \mathrm{a}$ dan $7 \mathrm{~b}$ masing-masing menampilkan kurva prediksi koefisien gesek $\left(C_{F}\right)$ sebagai koefisien pembentuk resistensi total kapal $\left(C_{T}=C_{F}+C_{R}\right)$ antara kecepatan 9-14 knot pada pemuatan penuh dan kosong. Koefisien gesek atau koefisien yang dibentuk akibat adanya gesekan aliran terhadap permukaan kulit kasko senantiasa berkurang seiring dengan penambahan kecepatan kapal, namun sebaliknya koefisien resistensi gelombang (Gambar 8a dan 8b), menurunnya koefisien resistensi gesek ini disebabkan oleh menurunnya kecepatan aliran fluida di sekitar kasko sebagai akibat pergesekan antara kulit kasko dan aliran yang dilewati. Koefisien resistensi gelombang yang tergabung pada koefisien sisa $\left(C_{R}\right)$ besarannya sangat dipengaruhi faktor bentuk model kasko yang dikarenakan gerakan kapal. Pada muatan penuh model kasko $K_{3}$ dengan bentuk yang lebih langsing $(L / B=6,43)$ pada kecepatan jelajah $\left(V_{S}=11\right.$ knot $)$ memiliki koefisien resistensi gesek $\left(C_{F}=1,997 * 10^{-3}\right)$ dan sisa $\left(C_{R}=2,64 * 10^{-3}\right)$ sebagaimana ditunjukkan pada gambar 7a dan 8a. Hasil ini lebih rendah dibanding model kasko $K_{1}, K_{2}$ dan $K_{4}$ pada pemuatan dan kecepatan yang sama. Fenomena serupa terjadi pula pada pemuatan kosong, model kasko $K_{3}$ memilik koefisien resistensi gesek dan sisa yang lebih baik dibanding 3 (tiga) model lainnya sebagaimana ditunjukkan pada gambar $7 b$ dan 8b. Seiring dengan pengurangan resistensi model kasko kapal, hal ini secara langsung berdampak pada pengurangan konsumsi bahan bakar yang merupakan salah satu komponen pembiayaan terbesar dalam pengoperasian kapal. 


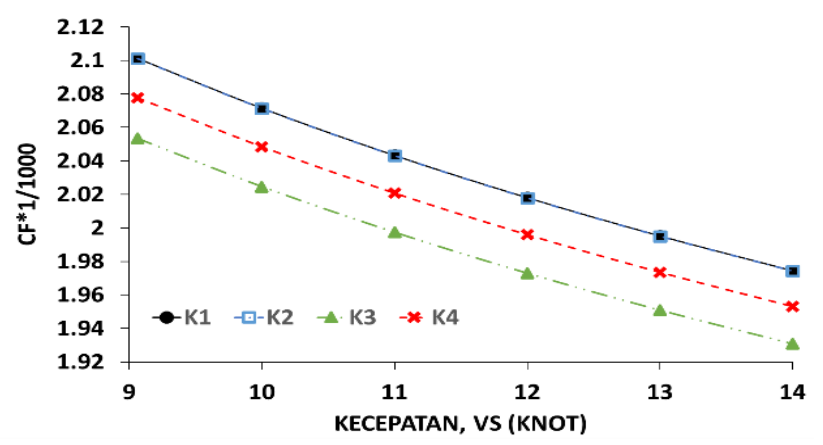

(a)

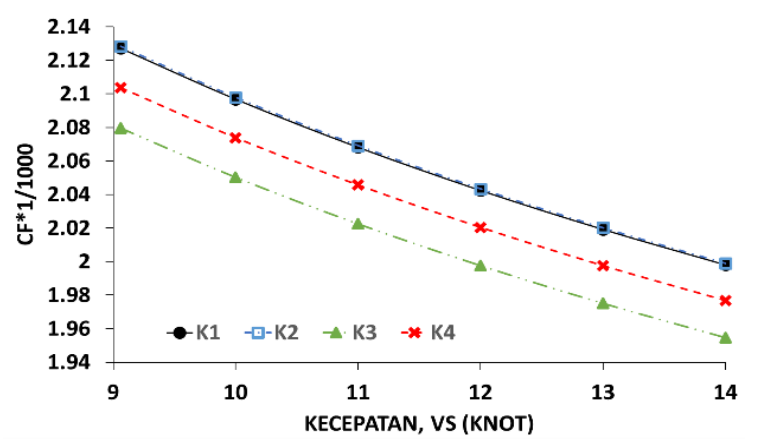

(b)

Gambar 7. Kurva koefisien gesek $\left(C_{F}\right)$ model kasko kapal. (a) Pemuatan penuh dan (b) Pemuatan kosong.

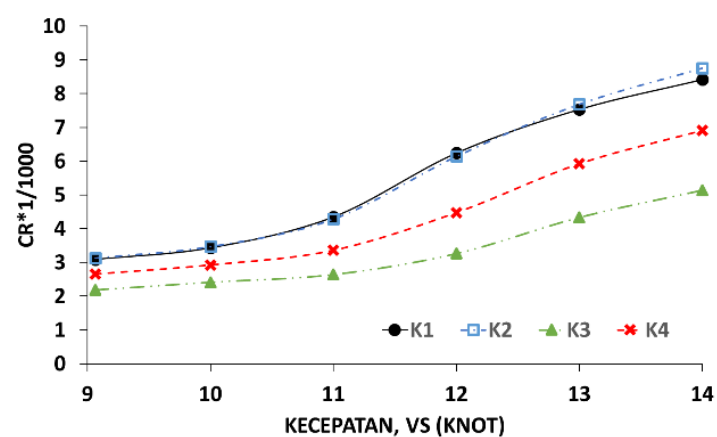

a) Pemuatan penuh

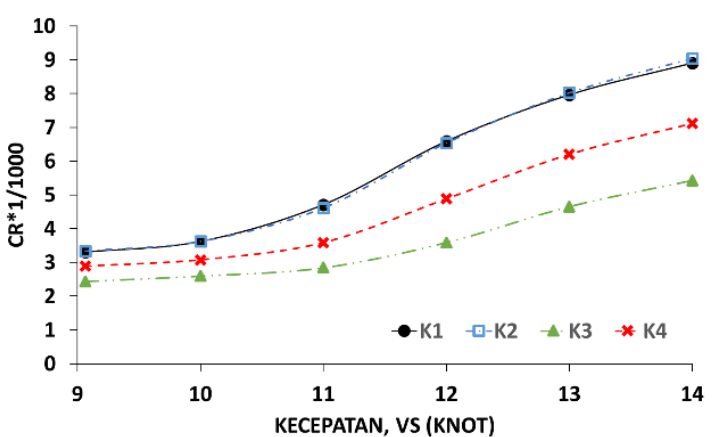

(b) Pemuatan kosong

Gambar 8. Kurva koefisien sisa $\left(C_{R}\right)$ model kasko kapal. (a) Pemuatan penuh dan (b) Pemuatan kosong.

\section{KESIMPULAN}

Pemodelan desain freeboard minimum model kasko kapal perikanan 30 GT terhadap tingkat keselamatan dan biaya operasional telah dianalisis melalui paket Program Maxsurf. Model Kasko $K_{l}$ sebagai kapal sampel dalam pemodelan ini merupakan kapal yang memiliki dimensi dan stabilitas yang baik sesuai kriteria IMO. Tingkat stabilitas kapal perikanan 30 GT meningkat seiring dengan penambahan rasio $B / D$, namun dengan penambahan rasio yang besar dapat memperburuk nilai resistensi kapal (model kasko $K_{2}$ ). Selanjutnya dengan melalui penambahan rasio $L / B$ pada displasmen konstan, secara signifikan mengurangi nilai resistensi kapal (model kasko $K_{3}$ ). Pengurangan nilai resistensi kapal ini secara langsung berdampak pada pengurangan konsumsi bahan bakar yang merupakan salah satu komponen pembiayaan terbesar dalam pengoperasian kapal. Secara umum, keempat model bentuk kasko yang dianalisis layak dioperasikan sesuai dengan kriteria $I M O$.

\section{UCAPAN TERIMA KASIH}

Penulis mengucapkan terima kasih kepada Lembaga Penelitian dan Pengabdian Masyarakat (LP2M) Universitas Hasanuddin, melalui pendanaan penelitian Benua Maritim Indonesia Spesifik (BMIS) SK No 14612/UN4.1/TU.21/2017 Tahun Anggaran 2017. Terima kasih pula khususnya kepada Mahasiswa yang tergabung dalam kelompok penelitian bersama pada LBE (Labo-Based 
Education) Propulsi Kapal Universitas Hasanuddin yang telah membantu dalam proses pemodelan simulasi komputer.

\section{DAFTAR PUSTAKA}

Azis, M.A., B.H. Iskandar, dan Y. Novita. 2017. Rasio dimensi utama dan stabilitas statis kapal purse seine tradisional di kabupaten pinrang. $J$. Ilmu dan Teknologi Kelautan Tropis, 9(1):19-28.

Behrendt, C. 2014. Energy saving technologies for fishing vessels. $J$. Scientific, 39(111):11-15.

Chorab, P. 2014. Sample calculations using a draft method for assessment of the vulnerability to pure loss of stability of a fishing vessel. J. Scientific, 40(112):39-46.

Holtrop, J. and G.G.J. Mennen. 1982. An approximate power prediction method, J. International Shipbuilding Progress, 29: 166-170.

Holtrop, J. 1984. A statistical reanalysis of resistance and propulsion data. $J$. International Shipbuilding Progress, 31: 272-276.

International Maritime Organization. 2002. Code on intact stability: Code on intact stability for all types of ships covered by IMO Instruments. International Maritime Organization. London. 27-28 pp.

Iskandar, B.H. dan S. Pujiati. 1995. Keragaman teknis kapal perikanan di beberapa wilayah Indonesia (Laporan Penelitian). Jurusan pemanfaatan sumberdaya perikanan, Fakultas Perikanan, Institut Pertanian Bogor. Bogor. 54 hlm.

Kuroda, T., H. Hashimoto, and R. Shigehiro. 2003. Relation between freeboard and capsizing risk for fishing vessels. In: Pérez-Rojas, L. (eds.). $8^{\text {th }}$ International Conference on the Stability of Ships and Ocean Vehicles. Madrid, Spain. 665-676 pp.
Muhammad, A.H., D. Paroka, S. Rahman, and Syarifuddin. 2015. Hydrodynamic characteristics of 30 GT fishing ship hull form in sulawesi waters. J. International of Engineering and Science Applications, 2(2):153-161.

Muhammad, A.H., Syarifuddin, D. Paroka, S. Rachman, Wisyono, dan A.A. Pratama. 2017. Performa maneuvering kapal perikanan 30 GT dengan konfigurasi propeler asimetrik. $J$. Ilmu dan Teknologi Kelautan Tropis, 9(2):491-498.

Marjoni, B.H. Iskandar, dan M. Imron. 2010. Stabilitas statis dan dinamis kapal purse seine di pelabuhan perikanan pantai lampulo kota banda aceh nanggroe aceh Darussalam J. Marine Fisheries, 1(2):113-122.

Nurdin, H.S., B.H. Iskandar, M. Imron, dan Y. Novita. 2013. Tata muatan dan variasi musim penangkapan pengaruhnya terhadap stabilitas purseseiner bulukumba, Sulawesi Selatan. J. Marine Fisheries, 4(2):183-193.

Novita, Y., N. Martiyani, dan R.E. Ariyani. 2014. Kualitas stabilitas kapal payang Palabuhanratu berdasarkan distribusi muatan. J. IPTEKS PSP, 1(1): 28-39.

Paroka, D. and N. Umeda. 2007. Effect of freeboard and metacentric height on capsizing probability of purse seiners in irregular beam seas. J. Marine Science and Tech., 12(3):150-159.

Susanto, A., B.H. Iskandar, dan M. Imron. 2011. Fishing vessel design and stability evaluation in palabuhanratu (case study of psp 01 training fishing vessel). J. Marine Fisheries, 2(2):213-221.

Zhao, H.L. 1997. The height of gravity center of ships. J. Marine Tech., 3:21-23.
Diterima
: $21 \mathrm{Mei} 2018$
Direview : $25 \mathrm{Mei} 2018$
Disetujui : 05 Juli 2018 